\title{
Ecological Footprint as a sustainability indicator to analyze energy consumption in a Portuguese textile facility
}

\author{
I. Costa ${ }^{1} \cdot$ F. G. Martins ${ }^{1} \cdot$ I. Alves ${ }^{1}$ \\ Received: 9 August 2017 / Accepted: 28 February 2018 / Published online: 7 March 2018 \\ (c) The Author(s) 2018. This article is an open access publication
}

\begin{abstract}
The main objective of this paper is to apply Ecological Footprint methodology as a tool to analyze the Portuguese textile industry. This analysis is related to energy and resources consumption in dyeing, printing and finishing processes. It also includes identification of mitigation measures to increase energy efficiency, promoting at the same time the reduction of $\mathrm{CO}_{2}$ emissions and consequently the decrease in industry's Ecological Footprint. Moreover, the analysis presents the Ecological Footprint reduction potential for each mitigation option proposed for an important textile facility located in the North Region of Portugal, used as a case study in this work. The results for the case study showed that the total Ecological Footprint accounted, for the year 2016, summed up to 4890 gha. Furthermore, the energy category corresponds to more than $50 \%$ of the total Ecological Footprint estimation, and natural gas was the most required fuel for the processes. The calculation of the Ecological Footprint in the textile facilities can be used as a tool to analyze the processes' energy efficiency and to quantify the global impact of the implementation of mitigation measures in the energy field. The result is an indicator shown in a common unit, gha (global hectare) and it can be easily used to compare energy-intensive processes and industrial sectors. In addition, it can be used to analyze how each sector can impact the country's total demand for resources.
\end{abstract}

Keywords Ecological Footprint $\cdot$ Textile facility $\cdot$ Sustainability indicator

\section{Introduction}

In 2016, Portugal consumed about 20 Mtoe, divided in oil (43\%), natural gas (20\%), coal (14\%), electricity (10\%) and biomass (13\%) [1]. Moreover, in the same year, Portugal was the seventh most energy-dependent country in the European Union (EU) [1]. Only 28\% (6 Mtoe) of the primary energy consumed in Portugal was produced internally $[1,2]$. The Portuguese industrial sector consumes about $30 \%$ of the total energy, which is more energy than the total produced in the country [3]. In the case of the textile and clothing industry, the consumption reaches $6 \%$ of the industrial consumption. Thus, it becomes crucial to implement plans for energy efficiency in this sector, reducing consumption to move towards a more sustainable environment and reducing the country's dependence on energy imports. Portugal is aligned with the

I. Costa

isabella@fe.up.pt

1 LEPABE, Departamento de Engenharia Química, Faculdade de Engenharia, Universidade do Porto, Rua Dr. Roberto Frias, 4200-465 Porto, Portugal
European Energy Efficiency Directive (2012/27/EU) and has a target for 2020 to reduce by $26 \%$ total energy consumption from 2012 projections [4]. The industry sector alone should reduce 34,500 toe per year from 2016 to 2020 [4].

In order to analyze the sector and propose energy efficiency measures in these processes, this work suggests the use of the Ecological Footprint (EF) methodology as a tool to study the energy consumption. A "footprint" is a quantitative measurement describing the appropriation of natural resources by humans [5]. It describes how human activities can impose different types of burdens and impacts on global sustainability [6]. Ecological Footprint is defined as a measurement of the human demand for land and water areas, and compares the human consumption of resources and absorption of waste with the Earth's ecological capacity to regenerate [7-9]. The EF provides an aggregated assessment of multiple anthropogenic pressures [10]. The method aims at determining the degree of sustainability of activities and regions/countries [11, 12]. The EF is both an accounting method and an aggregate indicator. The accounting method converts the flows of energy to and from a specific activity into a corresponding land area that is required to support these flows [13-15]. The method 
considers different types of land categories such as, built up land, fishing-ground, forest land, grazing land, fossil land, arable land [14]. Ecological Footprint can be used to analyze industry sectors, specifically, the textile sector [16-19]. Moreover, it allows to quantify globally the sustainability performance of this type of facility [16-20]. This specific characteristic differs this indicator from others already established and often used by researchers in the field (i.e. indicators used in GRI Reports and Greescope Reports). These indicators demand great amount of technical data, that may be not available, and its results require scientific specialists know-how to be analyzed and understood [21, 22].

The main objective of this paper is to apply EF methodology as a tool to analyze the Portuguese textile industry. This analysis is related to energy and resources consumption in dyeing, printing and finishing processes. It also includes identification of mitigation options to increase energy efficiency, promoting at the same time the reduction of $\mathrm{CO}_{2}$ emissions and consequently the decrease in industry's EF. Moreover, the analysis presents the EF reduction potential for each mitigation option proposed for an important textile facility located in the North Region of Portugal, used as a case study in this work. The scientific literature cited in the present paper, showed methodologies and observations that should be taken into account when applying Ecological Footprint methodologies, but it did not present the impact of implementation of measures for increasing energy efficiency in textile facilities. It is worth mentioning that there is a lack of analysis in the scientific literature related to applying Ecological Footprint methodologies to the Portuguese textile sector and to the proposal of specific mitigation alternatives to reduce energy consumption, at the same time, and it is covered by this paper.

\section{A textile facility}

A textile facility can incorporate different processes such as weaving, dyeing, printing and finishing in the same unit or in separate ones, which results in products of high quality. Weaving is a method of textile production in which two distinct sets of yarns or threads are interlaced at right angles to form a fabric or cloth. Similar methods are knitting, felting, and braiding or plaiting. The longitudinal threads are called the warp and the lateral threads are the weft or filling [23]. In the case of dyeing, it promotes coloring to the fabrics and various types of dyes are added to the mesh in order to obtain the desired color. These operations are carried out in aqueous solutions, at temperatures between 20 and $130{ }^{\circ} \mathrm{C}$. The printing process consists of transferring a colored material to the using a frame surface. After printing, it is necessary to dry to avoid spreading the material. The fixation can be done by vaporization or thermofixation [23]. After going through the stages of dyeing and/or printing, the meshes are sent to the finishing section. As already mentioned, depending on the purpose of the produced fabric, it can go through several stages of finishing inside the factory, always ending up in the drying machinery.

These processes allow the fabric to have the desired color, texture and dimensional stability, as well as the uniformity of these properties. In these sections, the mesh runs through a variety of chemical and mechanical processes. Depending on the purpose of the mesh produced, it can be processed in all three units such as dyeing, printing and finishing, or just one of these, with all meshes going through the finishing section. Textile companies' processes, concerning energy consumption, require mostly natural gas, electricity and steam. In addition, these companies can use a small amount of propane gas, and diesel, for the transportation fleet $[9,23,24]$.

As mentioned before, the textile sector is an energyintensive industry and must be analyzed in order to reduce its consumption and look towards a more sustainable way of producing high quality fabrics. The following sections presents the methodology for Ecological Footprint estimation in an organization and it is applied to a case study (a real textile facility in Portugal).

\section{Ecological Footprint estimation}

The total EF estimation should consider all resources (materials, water, energy, waste) that are part of a process or an organization. In the case of a textile facility, all accounted inputs and outputs, which are present in these processes, can be divided into three main categories: resources (water and materials), energy and waste. All inputs and outputs concerning the processes/organizations should appear in an inventory table, indicating each input/output and the amounts consumed/used [16-20, 25].

Each footprint category is calculated based on following equations, which are divided in several categories. The Resources Footprint, calculated by Eq. (1) is given by [9, 14]:

$F_{\text {resources }}($ gha $)=\sum\left(R_{\mathrm{i}} / \mathrm{NP}_{\mathrm{i}}\right) * \mathrm{EF}_{i}$,

where $F_{\text {resources }}$ is the total footprint for resources input, $R_{i}$ is the consumed amount of resource $i$ per year; $\mathrm{NP}_{i}$ is the natural productivity, expressed in $\mathrm{t} / \mathrm{ha} / \mathrm{year}$, of each product/ resource and, $\mathrm{EF}_{i}$ is the equivalence factor for the land use type producing products.

Equation (2) is used to estimate the energy category [14, $15]$.

$F_{\text {energy }}($ gha $)=\sum\left(P_{i} / Y_{i}\right) * \mathrm{EF}_{i}$

where $F_{\text {energy }}$ is the total footprint for energy input, $P_{i}$ is the consumed amount of energy per year; $Y_{i}$ is the average world 
annual yield for the product $i$ (or carbon dioxide absorbing capacity).

The waste footprint estimation was based on $[9,12]$. It should be calculated in the same way as for resources, using the same energy intensity and/or natural productivity of the material that originated the waste. It is worth mentioning that, in the case of recycled waste (RW), the percentage of recovered energy by recycling should be subtracted from the total EF estimation. The waste footprint (urban and nonhazardous waste) can be estimated by Eq. (3):

$F_{\text {waste }}($ gha $)=\sum\left(W_{i} / \mathrm{NP}_{i}\right) * \mathrm{EF}_{\mathrm{i}}$,

where $F_{\text {waste }}$ is the total footprint for waste output and, $W_{i}$ is the produced amount of waste per year.

The emissions footprint $\left(F_{\text {emissions }}\right)$ is calculated by Eq. (4), which represents $\mathrm{CO}_{2}$ emissions related to fossil fuels consumed in the facility/organization.

$F_{\text {emissions }}($ gha $)=\sum\left(\mathrm{tCO}_{2} \mathrm{e}_{i} / Y_{i}\right) * \mathrm{EF}_{i}$

The total Ecological Footprint is evaluated based on Eq. (5).

Ecological Footprint (gha) $=F_{\text {resources }}+F_{\text {energy }}+F_{\text {waste }}+F_{\text {emissions }}-\mathrm{RW}$

where $F_{\text {resources }}$ is the total resources footprint; $F_{\text {energy }}$ is the total energy footprint; $F_{\text {waste }}$ is the total waste footprint; $F_{\text {emissions }}$ is the total emissions footprint and RW is the total recycling waste footprint.

The next section presents the case study of a real textile facility in the North Region of Portugal and the proposed methodology applied to assess, mainly, its energy consumption.

\section{Case study: textile industry in North of Portugal}

The case study is focused on a textile facility unit with dyeing, printing and finishing processes. This unit uses as an input cotton fabric, which will receive treatment going through these processes. It is worth highlighting that this studied unit does not produce the fabric itself but treats it in order to obtain the desired final product ordered by its customers. It is worth to mention that the most required input by this facility was energy. In 2016 (year of available data), this Portuguese Textile Unit consumed about 2230 toe to produce near $3000 \mathrm{t}$ of final product (colored, printed and finished fabrics) and its $\mathrm{CO}_{2}$ emissions were around 7 $\mathrm{ktCO}_{2} \mathrm{e} /$ year.

The facility's available data were collected and is presented in Table 1. Besides the inventory of the facility's
Table 1 Portuguese textile facility's collected data Source: prepared by the authors

\begin{tabular}{lll}
\hline Input $^{\mathrm{a}}$ & Values $^{\mathrm{b}}$ & Units \\
\hline Resources & & \\
Paper and labels & 7800 & $\mathrm{~kg}$ \\
Water & 212,225 & $\mathrm{~m}^{3}$ \\
Energy & & \\
Natural gas (dry) & 1635 & toe \\
Diesel & 21.5 & toe \\
Propane & 0.8 & toe \\
Electricity & 566 & toe \\
Waste & & \\
Fabric (waste) & 430,000 & $\mathrm{~kg}$ \\
CO ${ }_{2}^{\mathrm{e}}$ emissions & 7.0 & $\mathrm{ktCO}{ }_{2}^{\mathrm{e}}$ \\
Output & & $\mathrm{kt}$ \\
Production (finished fabric) & 3 & \\
\hline
\end{tabular}

${ }^{\mathrm{a}, \mathrm{b}}$ All data were based on the facility's records for the year 2016 available data, conversions factors were used to estimate each category footprint. These factors are shown in the Table 2. Table 3 presents the equivalence factors used for each land category.

The total Ecological Footprint accounted, for the year 2016, summed up to 4890 gha. The calculations were supported in Eqs. (1)-(5) and data available on Tables 1, 2 and 3. The Resources Footprint estimation is 209 gha, representing less than $5 \%$ of the total Ecological Footprint, as the use of raw materials in the studied processes is limited. In the case of Energy Footprint estimation, the result is 2613 gha, which represents almost $50 \%$ of the total footprint and is mainly due to the use of high amounts of electricity and thermal energy. In the case of the Waste Category, the footprint reached about 90 gha, since there weren't a significant amount of disposable materials. Finally, for the $\mathrm{CO}_{2} \mathrm{e}$ emissions footprint, the result is 1978 gha, also representing almost $50 \%$ of the total footprint, connected to the intensive use of energy in the analyzed processes.

It is worth mentioning that for this particular facility there is no waste recycling concerning these processes, so it was not considered in this study. The wastes considered in the analysis were pieces of fabric that either were not used or were cut-off. The liquid effluents were not accounted as well because they are usually disposed in the effluent treatment station, located next to the facility and run by the Portuguese 
Table 2 Conversion factors Source: prepared by authors

\begin{tabular}{lllll}
\hline Source & $\begin{array}{l}\text { Embodied } \\
\text { energy }^{\mathrm{b}}(\mathrm{GJ} / \mathrm{t})\end{array}$ & Natural productivity $^{\mathrm{c}}$ & $\begin{array}{l}\text { Emission factor } \\
\left(\mathrm{tCO}_{2} \mathrm{e} / \text { toe }\right)\end{array}$ & Land category $^{\mathrm{d}}$ \\
\hline $\begin{array}{l}\text { Cotton fabric } \\
\begin{array}{l}\text { Paper and labels } \\
\text { Energy }\end{array}\end{array}$ & 10 & 1 (t/ha/year $)$ & & Arable land \\
Water $^{\mathrm{e}}$ & 30 & $1(\mathrm{t} / \mathrm{ha} /$ year $)$ & 3.078 & $\begin{array}{l}\text { Forest land } \\
\text { Fossil land }\end{array}$ \\
\hline
\end{tabular}

${ }^{\mathrm{a}}$ Energy sources footprint and emissions footprint were estimated based on $\mathrm{CO}_{2} \mathrm{e}$ emission factor and fossil land absorption rate $\left(3.666 \mathrm{tCO}_{2} \mathrm{e} /\right.$ toe $)[9,12,35,37]$

${ }^{b, c, d}$ Embodied energy, natural productivity and land category data were based on $[9,12,35,37]$

${ }^{\mathrm{e}}$ Total water consumption for these processes was due to steam generation and aqueous dyeing solutions. The company only kept record of the water used with chemicals. The water used for steam generation was estimated based on [24]
Table 3 Equivalence factors Source: prepared by authors based on [9, $12,35,37]$

\begin{tabular}{ll}
\hline Land category & Factor (gha/ha) \\
\hline Arable land & 2.1 \\
Forest land & 1.4 \\
Fossil land & 1.4 \\
Pasture land & 0.5 \\
\hline
\end{tabular}

Government. This work considered the water used in the processes as a resource and avoided double counting by transferring the responsibility for the industrial effluents to the Treatment Station.

Furthermore, the built-up land related to the facility, occupied area and the existing machinery were not accounted as well. This paper assumed that its focus is the process of dyeing, printing and finishing fabrics and all resources (materials, energy and water) that should be acquired and disposed every month in order to deliver the final products. Also, the dyeing chemicals data were not available and it was not accounted in this study. However, according to the studied facility, the amount used for these components is not too significant, its impact being negligible in the global figures.

The energy category corresponds to more than $50 \%$ of the total EF estimation for the studied company and, natural gas was the most required fuel for the processes. It is important to highlight that the actual methodology for estimating EF does not include final products from studied processes in the analysis, i.e. finished fabrics. According to the actual methodology, final consumers should take full responsibility for the products [21]. However, the scientific literature indicates that the methodology should be updated and the responsibility for the final products should be divided amongst the producers and the consumers [26, 27]. If that was the case in the study, the total EF could reach up to 8000 gha and the energy category would correspond to about $30 \%$ of the total result. In addition, if the producer alone took responsibility for the products and included it in the analysis, the total EF would be up to 10,000 gha and energy would be about $25 \%$ of the total.

The analysis showed that energy consumption is a significant portion of the total EF of the textile facility. Energy, specially thermal energy, is one the most required resource by processes such as printing, dyeing and finishing, that leads to the need to study mitigation measures in order to promote increased efficiency and consumption reduction $[17,19,28,29]$.

\section{Energy consumption mitigation measures}

Some mitigation measures were identified and could be implemented in the facility to reduce energy consumption, $\mathrm{CO}_{2} \mathrm{e}$ emissions and, consequently, the EF.

One energy consumption mitigation measure that could be implemented is the reduction and control of compressed air leaks. In 2016, it was verified, in the textile installation, an average leakage of about $40 \%$ of the produced compressed air. According to [24, 30-33], considering a frequent maintenance of the compressors, it could reduce its leakage to about $10 \%$ and consequently reduce electricity consumption and save up to 10 toe/year.

Other example of mitigation option is to install equipment to control gas combustion and avoid unnecessary steam generation in boilers, which can reduce natural gas consumption by $6 \%[24,30,33]$. In the case of the facility, it can save up to 48.7 toe/year in each boiler. Considering that the facility has 2 boilers, the total reduction can reach up to 97.4 toe/ year.

Also, installation of an air/water heat exchanger in the finishing machinery could save about $5 \%$ of total energy [31-33]. In the case of the studied facility, there are two machines that, together, can save up to 93.4 toe/year, by installing the referred equipment.

Moreover, an additional measure is the installation of photovoltaic panels to produce electricity in loco [24, 32, $33]$. According to the company, there is an available area of 
about $520 \mathrm{~m}^{2}$, in which 300 panels could be installed. It was estimated that it would generate $112 \mathrm{MWh}$ per year, considering a capacity factor of $15 \%$ [32-34]. This alternative could reduce the consumption of electricity from the grid in about 10 toe/year. Considering that this is a renewable energy source it would reduce $\mathrm{CO}_{2} \mathrm{e}$ emissions in about 30 $\mathrm{tCO}_{2} \mathrm{e} /$ year. Furthermore, the replacement of existing lighting for LED devices could save up to 9.5 toe/year in electricity consumption [30, 33, 35].

All the options can be implemented at the same time, so the total energy reduction is a sum of all energy reductions presented in this study. The total energy reduction potential for the studied facility is up to 220.5 toe/year. It consequently would reduce the EF of this facility by approximately 260 gha, which corresponds to a $5.3 \%$ of the company's EF.

\section{Final remarks}

According to National Laws, Portuguese facilities consuming more than 500 toe/year are framed as energy-intensive facilities [36]. In the case of the textile facility analyzed in this study, the energy consumption is about 2300 toe/ year which is higher than the limit presented. Thus it should be analyzed in order to implement an Energy Consumption Rationalization Plan.

The energy consumption mitigation proposals presented in this paper are considered as a first step towards implementing the referred plan. According to the results, it could reduce about $10 \%$ of the total energy consumption for the textile facility studied.

Furthermore, the bottom-up approach required by the EF methodology allows identifying the consumption by type of energy and resources. Consequently, it was possible to determine the processes' segments that are most energy-intensive. In the case analyzed in this paper, the processes of dyeing and finishing were the largest energy consumers, and the most consumed type of energy was thermal energy. This methodology allowed to investigate each part of the studied processes including energy efficiency and, at the same time, it enabled a global efficiency analysis to be done, that includes not just energy, but all the resources.

It is worth mentioning that this is an important analysis, especially for Portugal, that is part of an European Union group of countries that are engaged on the task force to reduce energy consumption in Textile Sector [33]. Countries like Germany, Spain, Italy, France and United Kingdom, together, account for about three quarters of European Union textile production and have reported projects concerning energy efficiency in the sector [33]. However, unlike these members of the task force, Portugal have showed less improvements over the years, because in the Portuguese textile sector, there are still many small facilities that function with equipment with very low efficiency and do not keep record of their consumption [23, 33]. This study can encourage these facilities to start reporting their data and be engaged on programs to reduce its energy consumption through increased investments in the latest best available industry practices, even though the National Government does not require it yet. Besides it, Portugal is strongly dependent on resources import, such as energy and materials, as mentioned before. The Global Ecological Footprint for Portugal, in 2016, was 3.88 gha/person [7]. The Portuguese biocapacity, in 2016, was $1.51 \mathrm{gha} /$ person, so it has a deficit of $2.37 \mathrm{gha} /$ person, which explains the Portuguese high dependency on international resources [7] and by increasing energy efficiency in industrial sectors, it could reduce its Ecological Footprint deficit.

Overall, the calculation of the EF in the textile facilities can be used as a tool to analyze the processes' energy efficiency and to quantify the global impact of the implementation of mitigation measures in the energy field. The result is an indicator shown in a common unit, gha (global hectare) and it can be easily used to compare energy-intensive processes and industrial sectors. In addition, it can be used to analyze how each sector can impact the country's total demand for resources.

Acknowledgements This work was the result of the project NORTE.01.0145.FEDER.000005-LEPABE-2-ECO-INNOVATION, supported by North Portugal Regional Operational Programme (NORTE 2020), under the Portugal 2020 Partnership Agreement, through the European Regional Development Fund (ERDF).

\section{Compliance with ethical standards}

Conflict of interest On behalf of all authors, the corresponding author states that there is no conflict of interest.

Open Access This article is distributed under the terms of the Creative Commons Attribution 4.0 International License (http://creativeco mmons.org/licenses/by/4.0/), which permits unrestricted use, distribution, and reproduction in any medium, provided you give appropriate credit to the original author(s) and the source, provide a link to the Creative Commons license, and indicate if changes were made.

\section{References}

1. Enerdata.: Global energy statistical yearbook-2017. https://www. enerdata.net/publications/world-energy-statistics-supply-anddemand.html (2017). Accessed July 2017

2. Eurostat: Key figures on Europe. http://ec.europa.eu/eurostat/ documents/3217494/7827738/KS-EI-16-001-EN-N.pdf/bbb5a f7e-2b21-45d6-8358-9e130c8668ab (2016). Accessed Jan 2017

3. DGEG: Portugal energy and geology headquarters. http://www. dgeg.pt (2016). Accessed Mar 2017

4. IEA: Energy policies of IEA countries-Portugal 2016 review. https://www.iea.org/publications/freepublications/publication/ Energy_Policies_of_IEA_Countries_Portugal_2016_Review.pdf (2016). Accessed Mar 2017 
5. Hoekstra, A.Y.: Water scarcity and international trade: the need to extend the scope of water resources management. In: Bastian, C., Gunkel, A., Leistert, H., Menniken, T., Rhodius, R., Schlipphak, B. (eds.) Wasser-Konfliktstoff des 21, pp. 121-141. Jahrhunderts, Universitätsverlag Winter, Heidelberg, ISBN 978-3-82535484-8 (2008)

6. UNEP/SETAC: Guidelines for social life cycle assessment of products, United Nations Environment Program. (2009)

7. GFN: Global Footprint Atlas. http://www.footprintnetwork.org/ content/images/uploads/Ecological_Footprint_Atlas_2010.pdf (2016). Accessed Mar 2016

8. Ferng, J.: Applying input-output analysis to scenario analysis of Ecological Footprints. Ecol. Econ. 69, 345-354 (2009)

9. Butnariu, A., Avasilcai, S.: Research on the possibility to apply Ecological Footprint as environmental performance indicator for the textile industry. In: Procedia-social and behavioral sciences, vol. 124, pp. 344-350. (2014),

10. Galli, A., Wiedmann, T., Ercin, E., Knoublauch, D., Ewing, B., Giljum, S.: Integrating ecological, carbon and water footprint into a "footprint family" of indicators: definition and role in tracking human pressure on the planet. Ecol. Ind. 16, 100-112 (2012)

11. Vogelsang, K.: Ecological Footprint forecasts face sceptical challenge. Nature 419, 656 (2002)

12. Wackernagel, M., Schulz, B., Deumling, D., Linares, A.C., Jenkins, M.: Tracking the ecological overshoot of the human economy. PNAS 99(14), 9266-9271 (2002)

13. Van den Bergh, J., Grazi, F.: Ecological Footprint policy? Land use as an environmental indicator. J. Ind. Ecol. Yale Univ. (2013)

14. Zhang, L., Dzakpasu, M., Chen, R., Wang, X.: Validity and utility of Ecological Footprint accounting: a state-of-the-art review. Sustain. Cities Soc. 32, 411-416 (2017)

15. Borucke, M., Moore, D., Cranston, G., Gracey, K., Iha, K., et al.: Accounting for demand and supply of the biosphere's regenerative capacity: the National Footprint Accounts' underlying methodology and framework. Ecol. Ind. 24, 518-533 (2013)

16. Chambers, N., Simmons, C, Wackernagel, M.: Sharing nature's interest: Ecological Footprint as an indicator of sustainability. ISBN: 978-1-85383-738-8, chapter 9. pp. 145-152. (2014)

17. Herva, M., Franco, A., Ferreiro, S., Alvarez, A., Roca, E.: An approach for the application of the Ecological Footprint as environmental indicator in the textile sector. J. Hazard. Mater. 156(13), 478-487 (2008)

18. Herva, M., et al.: New insights on ecological footprinting as environmental indicator for production processes. Ecol. Indic. 16, 84-90 (2012)

19. Herva, M., Roca, E.: Ecological Footprints in the textile industry. Handbook of life cycle assessment (LCA) of textiles and clothing, chapter 3. pp. 63-82. (2015)

20. Muthu, S.: Handbook of life cycle assessment (LCA) of textiles and clothing a volume in woodhead publishing series in textiles. ISBN: 978-0-08-100169-1 Woodhead Publishing Series in Textiles, pp. 63-82 (2015)
21. Kitzes, J., et al.: A research agenda for improving national Ecological Footprint accounts. Ecol. Econ. 68, 1991-2007 (2009)

22. GRI (Global Reporting Initiative): GRI's combined report for 2014-2015. https://www.globalreporting.org/resourcelibrary /GRIs\%20Combined\%20Report\%202014-2015.pdf (2015). Accessed Jan 2017

23. CITEVE: Portuguese textile industry-energy efficiency. https:// www.citeve.pt/artigo/energia (2017). Accessed June 2017

24. Costa, S.: Energy assessment of portuguese textile industry. Dissertation to Masters Degree, Department of Mechanical Engineering-University of Porto, Portugal (2014)

25. Doménech J.: Methodology guide for calculating the enterprise Ecological Footprint. In: Third international meeting over sustainable development and villages (in Spanish), Málaga University, Spain (2006)

26. Gallego, B., Lenzen, M.: A consistent input-output formulation of shared consumer and producer responsibility. Econ. Syst. Res. 17(4), 365-391 (2005)

27. Lenzen, M., Murray, J., Sack, F., Wiedmann, T.: Shared producer and consumer responsibility - theory and practice. Ecol. Econ. 61(1), 27-42 (2007)

28. Oyedepo, S.: Efficient energy utilization as a tool for sustainable development in Nigeria. Int. J. Energy Environ. Eng. 3, 11 (2012)

29. Vilcekova, S., Burdova, E.: Multi-criteria analysis of building assessment regarding energy performance using life-cycle approach. Int. J. Energy Environ. Eng. 5, 83 (2014)

30. Hasanbeigi, A., Price, L.: Technical review of emerging technologies for energy and water efficiency and pollution reduction in textile industry. J. Clean. Prod. 95, 30-44 (2015)

31. European Commission: BREFS-Integrated Pollution Prevention and Control. http://eippcb.jrc.ec.europa.eu/reference/BREF/ txt_bref_0703.pdf (2003). Accessed July 2017

32. Bayat, M., Ozalp, M.: Energy, exergy and exergoeconomic analysis of a solar photovoltaic module. Exergetic, Energetic and environment dimensions, chapter 2.10. pp. 383-402. (2018)

33. SET: Save energy in textile facilities. http://euratex.eu/fileadmin/ user_upload/documents/Library/R_D/SET_Final_Report_Web. pdf (2016). Accessed Sept 2017

34. Sampaio, P., Gonzalez, M.: Photovoltaic solar energy: conceptual framework. Renew. Sustain. Energy Rev. 74, 590-601 (2017)

35. Portuguese Ministry of Economy and Innovation: Informative note SGCIE (2017), Portuguese Energy Agency. http://www.adene.pt/ consumo-energetico-na-industria (2008). Accessed June 2017

36. SGCIE: Portuguese Energy Agency. http://www.adene.pt/consu mo-energetico-na-industria (2017). Accessed June 2017

37. Coto-Millan, P., Quesada, J., Manteco, I.: Research letter corporate Ecological Footprint: new conversion factors research letters in ecology, p. 4. (2008)

Publisher's Note Springer Nature remains neutral with regard to urisdictional claims in published maps and institutional affiliations. 